\title{
What's the Matter with "China"? A Critique of Teleological History
}

\section{HUGH R. CLARK}

This article argues that the study of China's history has long been caught in a teleological trap that presumes that history could have had only one evolutionary track. The author explains how he came to recognize the problems inherent in the teleological trap and to reconceptualize his approach. The article contrasts the history of the North China Plain, culturally rooted in dry-land grain agriculture and from time immemorial deeply intertwined with that of the adjacent grasslands, with that of the south, a culturally and linguistically diverse land of river valleys and riziculture. It concludes that the holistic empire we know today was not an inevitable outcome of these contrasting trajectories and that alternative paths are plausible, and asserts that scholars must recognize that until history is accomplished it does not follow a teleological trajectory.

Keywords: China, historiography, holism, North China Plain, riziculture, Sinitic, teleology, Yangtze basin, zhong guo

A FTER MANY YEARS OF focus on southern Fujian, over the past decade my work increasingly has engaged the relationship between the original inhabitants of the south, which I define as the Yangtze River basin and all that lies below, and Sinitic immigrants. Throughout the first millennium CE, these migrants flowed from north to south, sometimes from the Central Plain to the basin of the Yangtze River, but equally often from that basin to areas further south (see especially Clark 2016). This issue has gradually intruded into my approach to China's more distant past and how I frame my questions.

Early in my career I was struck by an historical paradox, which I noted in the preface to a 1991 study of the economics of southern Fujian in the Tang and Song: "It is a fascinating twist of history that China evolved largely as a political whole while Europe has been fractured through most of its evolution. Both land masses had ample opportunity to develop in either direction" (Clark 1991, 1). In other words, why did one end of the Eurasian continent evolve through competition between myriad courts, kingdoms, and nation-states, while across a roughly equal territory at the other end the model that gained traction was holistic empire?

If I saw the paradox, however, I was not yet open to the depth of the tension it engages. Like most historians of that corner of southeastern Eurasia that we call "China," I accepted the paradigm that holistic empire was the norm and fracturing was the aberration, a paradigm that has run through the study of "China" at least since the path-breaking eleventh-century historiography of Ouyang Xiu and Sima Guang, for whom the normalization of the holistic model was more than mere cultural centrism. The Song had emerged in the later tenth century out of the chaos that had bedeviled

Hugh R. Clark (hclark@ursinus.edu) is Professor Emeritus of History and East Asian Studies at Ursinus College. 
the Central Plain for a century. The reunified empire stood in remembered contrast to the chaos of the alternative; it was a political resolution. But as that chaos receded into a more distant past, the perpetuation of the paradigm more and more became an ideological assertion, a defining feature of "Chinese-ness." And it ignored a critical reality: at least until the Sui/Tang era, the holistic model had been the aberration, fracturing the norm. As I argued in 2016, even in Sui/Tang the holistic empire was a superficial overlay on a far more complex reality. ${ }^{1}$

My failure at the time to recognize this, a failure that I broadly shared with scholars of China's distant past, freighted the answers I could reach. And here is where I want to focus the essay that follows. We know today that Europe is many-it is many languages; it is many nation-states; it is at least three embracing yet exclusive Christianities as well as Judaism and Islam.... It is many "manys." In contrast, we engage China as one. It is one nation-state (if we do not count Taiwan or Singapore, to say nothing of Tibet or Xinjiang); it has a unifying language (if we neglect the continued role of so many regional "dialects"); absent a single unifying religion akin to Christianity, there is a universal culture that could be called Confucio-Buddho-Daoism (if we overlook Islam or the vast number of regional and local cult deities). In our classrooms we might teach European history or we might teach French history. We also might teach Chinese history, but does anyone teach the history of Fujian or Henan, even in China? And should a course be defined through place-say, a course on Shanghai or Beijing (as I taught several years ago in Beijing)_ inevitably it is intended to provide a regional or local perspective on holistic China, for what is a locality today except a window toward understanding the whole?

Thus we are presented with a fait accompli. The China that is, the holistic contrast to fractured Europe, is one. But did that have to be? Does a native of the Minnan region of southern Fujian, who speaks Minnan dialect, recoils from spicy foods, and is embedded in a local network of gods and lineages, have any more in common with a native of Hunan or Hebei, whose dialect is unintelligible, whose food is indigestible, and whose networks are completely unrelated, than a German has with a Spaniard? It is the premise of this essay, in fact, that scholars both within and outside China have for centuries perpetuated an historiographical error embracing a teleological construct that simplifies and thereby distorts a fundamental reality. My goal, therefore, is to challenge the teleological paradigm of "China," the presumption that the China that "is" today-the geopolitical entity that includes everything from the Yellow and Yangtze river basins to the deeper south, what is sometimes called the core eighteen provinces-has always been, in potential if not reality. Though it may have taken many centuries to realize in its fullness, the premise is that the integrity of contemporary China is ancient. ${ }^{3}$

\footnotetext{
${ }^{1}$ Most importantly see Clark (2016), in which this is an organizing theme, but also Clark (2014).

${ }^{2}$ Throughout the following discussion, terminology is a challenge. In an imperfect resolution, when referring to the teleological concept I will use quotes: "China"; when referring to contemporary geopolitical China, I will not use quotes. However, just as I assert that "China" is a false teleological construct, so I would claim that China is a contingent product of an historical narrative. Therefore, when referring to the culture, including especially both the language and the politics, of the Central Plain, I will identify it as "Sinitic."

${ }^{3}$ Parallel critiques have emerged in discussions of late imperial China in reference to the Manchu empire (especially Crossley 1999; Elliot 2001; Rawski 1998) and in discussions of contemporary China (Chow 1998; Zhang 2015).
} 
As a result of the immense progress of archaeology in China, for several decades now scholars have recognized that a wide range of ancient cultures contributed to the culture we call "Chinese." Yet historical studies both within China and abroad have continued to treat the modern, holistic state as the teleological outcome of an historical narrative that intrinsically had to be. One could point to numerous survey textbooks that remain in wide use throughout the world's classrooms. ${ }^{5}$ Among scholarly monographs, as recently as 2007, in his preface to the revised edition of his classic study of the northern regimes of the tenth century, originally titled The Structure of Power in North China during the Five Dynasties but now renamed Divided China: Preparing for Reunification, 883-947, Wang Gungwu (2007, ix) has written: "The oneness of China is the norm. Periods of Division are aberrations... The Chinese continue to be reminded how staunchly the ultimate indivisibility of China ... was upheld as an act of faith among the elites and how firmly the story of China is tied to this ideal." In short, this perspective would argue that historical forces drove eastern Asia toward the configuration we see today, and have seen for the past several centuries. A multi-state outcome akin to that of Europe has rarely been seen as a feasible alternative.

Contemporary China, however, is the culmination of several millennia of history that could have spun off in entirely different directions. Historians cannot tell a story that leads to an outcome at odds with present "reality"; the narrative of the past must stick to what has become, as teleological "China" has become contemporary China. It is equally fundamental, however, that historians must always keep in mind that what is yet to become is always contingent; at no point in the past was the next step certain until it was accomplished. Tradition may have long argued that "China" had to be, but my premise is that China, the nation-state that includes not just the core eighteen provinces but Manchuria, Tibet, and Xinjiang as well, in fact did not.

The flaws in the teleological paradigm have been remarked upon by a range of recent scholars. Jonathan Karam Skaff $(2012,4)$, for example, has referred to the "frog in the well syndrome":

The proverbial Chinese frog at the bottom of the well was complacent because of his ignorance of the world outside. Studies of pre-modern China often suffer from this syndrome. Historians who exclusively utilize Chinese language sources and chronological comparisons perpetuate a fallacy, common to national histories, that Chinese identity and history are unique products of internal evolution.

Similarly, Erica Brindley $(2015,62-63)$ commented recently that "views of Chinese ... history are informed by myths of what make the Chinese ... who they are today." She goes on: "Chinese archaeologists often participate in a regionalist approach that highlights a region’s (or province’s) local, distinctive traits while at the same time emphasizing its links to the glorious, unified tradition of China."

\footnotetext{
${ }^{4}$ Chang (1986), though dated, remains among the most influential surveys. The relevant chapters of Loewe and Shaughnessy (1999) are more recent but less thorough; also note Holcombe (2010) and Hansen (2015).

${ }^{5}$ Classics such as Reischauer, Fairbank, and Craig (1960) and Gernet (1982) are especially "guilty," but also more relatively recent works such as Ebrey (1996) adhere to the teleological construct even if they challenge the narrative, perhaps to satisfy unimaginative publishers.
} 
Both Skaff and Brindley have challenged a paradigm that is deeply embedded in Chinese studies and that begins with the emergence through the second and first millennia BCE of "Sinitic civilization" in the drainage basin of the Yellow River. As this civilized core, the self-styled "land at the center" (zhong guo 中國), came into contact with the "barbarians" on its peripheries, one by one they were overwhelmed by its cultural power. Witness, the paradigmists would argue, the spread of Sinitic writing and thought throughout the so-called Sinitic world: Korea and Japan, but also Vietnam, to say nothing of the alleged disappearance of "nearer" peoples such as the man and yue who once occupied the southern river valleys and coastline but have been thoroughly subsumed into the Sinitic world. ${ }^{6}$ It is this very universality, however, that points to the problem: Japan, Korea, and Vietnam, to say nothing of the ancient Khitan, Jurchen, Mongols, and Tabghach, to name but a few of the peoples who have controlled the peripheries of the "Chinese" world, all shared to some degree the cultural premises, the script, and the texts of Sinitic civilization, yet each remained distinct and separate. This has created a dynamic that at numerous times has challenged the integrity of "China."

\section{The Beginning of My Problem}

Although I initially framed the problem in the 1991 preface cited earlier, I trace my concerns to two anecdotes, which I think point to a paradox, and in the paradox a problem. Both derive from a research trip in 1989 to the Minnan region of southern Fujian Province on which my scholarship has built, and both involve the same colleague, a senior professor of history at Xiamen University.

The first involves an ancient lychee tree in the courtyard outside a small workshop in Putian district. The tree is unquestionably venerable, but without hesitation my colleague affirmed the received opinion of local scholars that the tree derives from the Tang dynasty. Leaving aside the plausibility of the claim, which he said had been verified by drilling a core sample (hardly the way to treat a tree that is claimed to be 1,200-1,300 years old!), what strikes me today is the unhesitating, and unreflective, assertion of the cultural integrity of "China" and of "Chinese" history that the tree embodies. The Tang, my colleague presumed, was the point in time when Fujian, which had long been passed by the Sinitic migration, was subsumed into larger "China," when Fujian was "civilized." To my colleague, this is embraced in the tree.

The second occurred several weeks later as we discussed the prospect of oil reserves in the Taiwan Strait, when he asserted that any oil found in the offshore waters would belong to Fujian. I protested that surely the oil would belong to China, but he insisted that indeed it would belong to Fujian. Fujian may have been part of that culturally integral thing we call "China," but when there is opportunity the benefit accrues to Fujian. It is separate.

\footnotetext{
${ }^{6}$ Skaff (2012) points especially at John King Fairbank as a Western perpetrator of this paradigm, but also at later scholars trained in Fairbank's approach, such as James Hevia (1995) and James Millward (1998). Recent Chinese scholarship like what one might find in ongoing series such as Zhongguo Yuexue 中國越學 (Studies of Yue in China) and Nanfang Minzu Kaogu 南方民族考古 (Archaeology of Southern Ethnicities) continue to treat the yue and man as anticipations of the holistic empire.
} 
I was bothered by the presumptions behind both exchanges, but at the time I did not fit them into a larger concern. Retrospectively, however, I see the tension between them at a more fundamental level. My colleague was the product of a traditional education that culminated in post-Revolution university training. His education had embraced two key premises: the long-standing paradigm of holism and the post-Revolution emphasis on a common brotherhood among multiple ethnicities that has been central to national identity in contemporary China. In his assertion about the lychee tree, he expressed this heritage of cultural and political holism. Yet he was also a native of Fujian. He may have regarded those from Henan or Sichuan as his countrymen, but when the interests of Fujian diverged from those of elsewhere, as they might if oil were found, he was a "man of Fujian," a Fujian ren, and that takes precedence.

Where does that leave the study of China? Is Fujian integrally part of China's centuries-long history? Or is Fujian something distinct, something apart? In fact, is there such a "thing" as "China"? That is the theme of the discussion that follows.

\section{The Origins of “China”}

The roots of "Chinese" culture emerged through the second millennium BCE out of a complex of late Neolithic cultures across the vast alluvial deposit known as the Central, or North China, Plain embracing the lower reaches of the Yellow River. This is identified in the historical narrative as the Shang, or Yin, dynasty. To the extent that there was a holistic Shang imperial structure, its reach did not extend beyond the Plain. Yet, much as the teleological narrative of Western civilization, embraced in countless undergraduate "Western Civ" courses and the accompanying textbooks, finds a root in the ancient cultures of Mesopotamia and the Nile River valley, so the teleological narrative of "Chinese Civ" finds a lineal antecedent in the ancient Shang. Although much about Shang culture today remains open to debate, the teleological argument asserts that from its origins in Shang, or even the semi-mythological Xia that preceded it, "Chinese" civilization has flowed uninterrupted to the present. This assertion is central to "Chinese" identity.

There is, in fact, general concurrence that Shang civilization is a very important root to the construct known today as "Chinese" civilization-much more so, one could argue, than Mesopotamia or Egypt was a root to later European culture. "Very important root," however, does not mean "without change," or even without disruption. Indeed, culturally and ethnically distinct invaders have commingled with indigenous people on the Central Plain numerous times, sometimes by invasion and others by migration, and each time the culture of the Plain has commingled with and accommodated to the new order.

The first such recorded event was when the people known in historical records as Zhou moved into the Central Plain in the late twelfth and early eleventh centuries BCE. Tradition embraced in later histories defines the Zhou people and state as products of the Shang cultural milieu who had migrated from the Shang periphery into the Wei River valley that lies west of the Central Plain. This is the heart of the high inland plateau known in Chinese historiography as "within the pass" (guan nei 關内), the classical allusion to the lands that lay west of the gap carved by the Yellow River where it pierces the mountain barrier formed by the Taihang and Qinling mountain ranges that together separate the mid-course of the Yellow River from its lower reaches that cross the Central 
Plain. "Within the pass" is the literal translation, yet the term might better be rendered "beyond the pass," for it arises from the cultures of the Central Plain who looked at the peoples who lay beyond the gap with foreboding.

In other words, much as later eras feared the Xiongnu, the Tabgach, or the Mongols as threats to civilization, so the Shang elite who framed the ancient civilization defined the Zhou as uncivilized and equally as a threat to civilization itself. Although the Zhou elite had adopted much of Shang technology and aspects of Shang culture and had their own increasingly sophisticated culture, the Shang elite, to whom "civilization" meant the elite culture of the Plain, saw them as uncivilized outsiders. The pass was the gap in the mountain barrier that otherwise afforded them protection. Thus, although the teleological narrative presents the Zhou as heirs to the Shang and the next great "Chinese" dynasty, ${ }^{7}$ in the eyes of the Shang elite they were violent "barbarians."

In fact, the Zhou indeed did mark a fundamental transformation. For the first time the Central Plain was under the authority of a culture rooted in the lands "beyond the pass" where the influence of the non-Sinitic world was felt much more keenly. Texts such as the Book of Odes, compiled in its present form many centuries after the Zhou conquest but including odes plausibly dated to near that time, suggest that the Zhou people had only recently adopted sedentary lifestyles (Shaughnessy 1999, 300-302). In fact, some argue, the Zhou for generations prior to their assault on the Central Plain had been more deeply tied to the migratory cultures of the Inner Asian steppe than to the agrarian civilization of the Shang. ${ }^{8}$

Nevertheless, the newly empowered Zhou made room for the deities of the Shang in their rituals, especially the supreme Shang deity known as Di. Within Zhou culture the power of Di was conceived as universal. The opening of the Book of Documents, where Di is equated with the legendary ruler Yao, asserts that "all under the Cosmos (tian) was his" (Shang Shu Quanjie 1999, 1:1b). There was no theoretical limit to the authority of $\mathrm{Yao} / \mathrm{Di}$, who brought peace to the "myriad lands." Equally important was the implicit presumption that only the Shang-Zhou culture marked civilization.

It is in this context that the term zhong guo, perhaps best interpreted as "the realm that sits in the center," gained currency. Zhong guo, the center, the land of Zhou, defined the civilized world: zhong guo was civilized, leaving everything else, what later came to be called wai guo, the "realms outside," to define the uncivilized. Possibly the oldest

\footnotetext{
${ }^{7}$ See, for example, Sima ([1807] n.d., 4), the opening juan of the Zhou "basic annals."

${ }^{8}$ The pre-conquest history of the Zhou people has been debated. Some have given credence to the tradition that traces their origins back to the periphery of the Central Plain, but others are equally sure they had no links to the Shang prior to the century or so before the conquest and arose instead from a syncretic culture emerging from "a fusion of several local prehistoric cultures" that expressed "an interplay between farming and seminomadic livestock-raising lifestyles" (Holcombe 2010, 31; see also Li Feng 2013, 113-20; Rawson 1999; Shaughnessy 1999). There is almost no written record from within Zhou culture that purports to be from prior to the Zhou conquest; thus our documentary evidence of pre-conquest Zhou culture has been mediated through the literary monopoly of Shang civilization. Archaeology has confirmed aspects of the last stages of preconquest Zhou, including the establishment of at least one site of enduring settlement, but what we can infer about what preceded that passes through the opaque window of the Shang scholarly tradition. Geography alone argues that the Zhou people had deeper ties to the cultures of Inner Asia than did the occupants of the Central Plain.
} 
surviving use of the term is an inscription on a bronze vessel dated to $1020 \mathrm{BCE}$ in which King Wu, having conquered Shang, informs the cosmic power tian that he "would make his home in zhong guo" (zhai zi zhong guo 宅茲中國). ${ }^{9}$ Similarly, the Book of Documents records that the Duke of Zhou, in his "Pronouncement on Alcohol," wrote: "The August Cosmic Power (huang tian 黄天) granted the people and lands of zhong guo to the former kings" (Shang Shu Quanjie 1999, 29:47b). To Sima Qian (ca. 140-86 BCE), the great historian of the Han dynasty whose Records of the Grand Historian provides the most comprehensive, if often fanciful, recounting of historical legends, the term alluded to the several kingdoms (guo 國) of the first millennium BCE that occupied the North China Plain; Sima frequently used it in direct contrast to terms generally translated into English as "barbarian." Notably, regarding the descendants of Wu Taipo, Sima wrote: "After he had defeated the Shang, King Wu [of Zhou] divided them. The line of Yu was located in the zhong guo, but that of $\mathrm{Wu}$ [Taipo] was among the southern barbarians (yiman 夷蠻)” (Sima [1807] n.d., 31:3b).

This leads back to the theme of universality. The zhong guo explicitly recognizes the duality of civilized versus uncivilized (see Ge 2011). But it sits at the center, around which everything else revolves; it was to the uncivilized what the Pole Star was to the heavensthe pivot. The Zhou invocation of centrality, therefore, did not challenge the universal claim of Di or of civilization. The power of both was perceived to be self-evident: they drew heretofore uncivilized lands into the culture of zhong guo, a central but hegemonic assumption of the teleological interpretation, as is stated in the late first millennium BCE Intrigues of the Warring States:

The zhong guo is the place where perspicacity and intelligence abide; where wealth gathers; where the sages teach; where benevolence and righteousness are practiced; where the Odes and the Documents, rites and music are employed; where genius and technique are tested; where distant places go to observe; where the Man and the Yi find their models of righteousness. ${ }^{10}$

When the Zhou court, faced with renewed threat from the farther west in the early eighth century BCE, fled from "beyond the pass" and resettled on the Central Plain, it sacrificed its political authority and became but one among a myriad of politically equal courts. The early Zhou pretense of inheriting the universal realm of the Shang, a pretense that had been maintained for several centuries, had collapsed. Although the civilization of the Plain remained the universal standard against which all others were judged, this was a time of localized political authority across the zhong guo and the emergence of two new polities on the frontiers: to the west, "beyond the pass" in the old Zhou homelands, was Qin; to the south, straddling the basin of the Yangtze River, was Chu. Following the conquest of Shang the Zhou realm had defined orthodoxy, but before the conquest in the eyes of the Shang the Zhou had been among the uncivilized. When the Zhou court retreated to the Central Plain, the quality of civilization "beyond the pass," now the land of Qin, was once again in doubt.

\footnotetext{
${ }^{9}$ See Wikipedia (2017) for a transcription and discussion of the text.

${ }^{10}$ Zhanguo ce, edited by (Han) Gao You, and revised by (Song) Yao Hongxu, 19:9b. I follow the translation of $\mathrm{Bol}(2009,17)$.
} 
As with Zhou, the origins of Qin are open to question. Sima Qian recounted a line of descent that linked Feizi, the alleged founder of the Qin kingdom, to the most ancient myths of the zhong guo. Sima was intent on linking the Qin royal family to an orthodox heritage, noting that Feizi was granted a fief by the Zhou court. He added, however, that Feizi was a horse and cattle breeder: "Feizi lived on 'Dog Hill.' He loved horses and cattle. He was good at tending to them and raised them." Thus the Zhou king gave him charge of the horses (Sima [1807] n.d., 5:1b-2a and 4a).

How much can we rely on sources that are so many centuries later? It is obviously a problem. As Sima was a subject of the Han court for whom discrediting the Qin was essential, we are well advised to take what he wrote cautiously. Nevertheless, he betrayed his effort to define the origins of Qin in civilized terms by identifying Feizi with the breeding of horses and cattle, definitive of the non-agrarian, non-sedentary lifestyle of the "uncivilized." Furthermore, he added that Feizi’s daughter had married "Rong Xuxuan," that is: "Xuxuan of the Rong." Feizi's family, in other words, had allegedly intermarried with the Rong, an ethnonym that defined the outer barbarian (Sima [1807] n.d., 5:5a). Whatever the origins of the Qin royal family may have been, Sima argued that by the time of Feizi they had thoroughly integrated with the "uncivilized" peoples "beyond the pass." Through the following centuries, Feizi's heirs were drawn into the politics and the discourses of the Central Plain, for after all, the orthodox narrative tells us, the appeal of civilization was universal. Whatever the origins of the Qin ruling elite, however, when Qin conquered the kingdoms of the Central Plain in the third century BCE, it was once again a conquest from "beyond the pass," from a region where the commitment to the values of civilization as defined by the shared culture of the Plain was deemed questionable.

This is more than "mere" ancient history, for it tells us something very important about the zhong guo that bears on much more recent history. From the very beginning of documentation, the line between the Sinitic world of the Plain and the non-Sinitic cultures that lay "outside," the worlds of the ancient Rong and later of the Di and $\mathrm{Hu}$ "barbarians" who occupied the lands to the west and north, has been far less absolute than the Sino-centric narrative that has structured Chinese historiography would suggest. Indeed, for much if not most of the past three thousand years the zhong guo-the world of Sinitic culture, the pivot around which all peoples revolved as that narrative would have us believehas been ruled from the "periphery." When the Zhou people conquered Shang they did not move their political center into the North China Plain but left it in the Wei River valley "beyond the pass" from whence they had come. There it remained until new invaders chased them to the east. When Qin — perhaps the descendants of those earlier invaders? conquered Zhou, once again their capital, their political center, was left "beyond the pass." The "periphery" thus defined the "center," and the "center" the "periphery."

The rule of the periphery did not stop there; indeed, over the next two thousand years it became even more pronounced. Qin and its successor ruling house Han engineered the first political unification of "China" in the four centuries across the millennia BCE to CE. There is little reason to doubt the Sinitic heritage of the Han elite. Nevertheless, as Di Cosmo $(2002,255)$ points out, through much of the Han era the "Xiongnu [both the Inner Asian empire and people] had become a phenomenon whose effects on Han life-military, economic, and political—could not be ignored." In short, the Han elite may have been rooted in the zhong guo, but the interaction between periphery and center, between the civilized and barbarian worlds, continued. Han, moreover, 
Table 1. Historical record of non-Sinitic dynasties, Zhou-Qing.

\begin{tabular}{lll}
\hline Non-Sinitic Dynasty & Region Conquered & Dates of Rule \\
\hline Zhou* & North China Plain & 1046-256 BCE \\
Qin* & Empire & 221-206 BCE \\
16 Kingdoms & North China Plain & $304-439$ CE \\
Non-Sinitic Northern Dynasties & North China Plain & $386-581$ CE \\
Khitan Liao & 16 Prefectures & $907-1125$ \\
Tangut XiXia & "Beyond the Pass" & $1038-1227$ \\
Jurchen Jin & North China Plain & $1126-1234$ \\
Mongol Yuan & Empire & $1260-1368$ \\
Manchu Qing & Empire & $1644-1912$ \\
& & \\
\hline
\end{tabular}

"Although Zhou and Qin define "Sinitic," both were conquest dynasties by peoples whose origins lay outside the Central Plain.

was followed by a renewed round of conquest from north and west. Wave after wave of non-Sinitic peoples rolled across the North China Plain, establishing short-lived polities known in the record as the Sixteen Kingdoms. These were followed by the more stable but still alien “northern" dynasties founded by the Tabgach (Ch. Tuoba 拓践), a clan from within the pastoral Xianbei people who had long occupied the eastern Mongolian grasslands. Once again the North China Plain was incorporated into the world of non-Sinitic conquerors. Even when the Tabgach Xiaowen emperor (r. 471-99) moved his capital to the Yellow River basin and mandated the adoption of Sinitic cultural norms, he maintained the political unity between the Plain and the grasslands that his predecessors had constructed. Although the holistic "empire" was reconsolidated in the late sixth century by Sui/Tang and the normative divide between "China" and the outside was reestablished, many of the Sui/Tang ruling elites were ethnically Turkic. As the Tang imperium was challenged through the ninth century, autonomous warlords in the northeast, themselves often of ill-defined cultural heritage, forged deals with the non-Sinitic peoples who lay "outside," and renewed connections with the north persisted from the tenth through the fourteenth centuries as Turks, Khitan, Jurchen, and finally the Mongols took larger and larger bites. And once again the North China Plain and then the entire empire was conquered from the northeast in the seventeenth century by the Manchu, a status that endured until the early twentieth century.

In fact, from the beginning of Zhou rule over the North China Plain in the late second millennium BCE until the collapse of the Manchu Qing dynasty at the close of the second millennium CE, the North China Plain, the alleged heartland of "Chinese" culture, the territorial zhong guo, has been ruled in whole or in part by peoples from "outside" for roughly two of the three millennia (see table 1). If we also recognize that the Tang ruling family was possibly of Turkish origin and certainly deeply entwined with non-Sinitic elites, we can add another three hundred years to that. ${ }^{11}$ If some conquerors

\footnotetext{
${ }^{11}$ Reflecting a growing trend in scholarship, the Tang ruling family has been increasingly defined as heirs to the centuries of Turkish control of the North China Plain rather than, as the orthodox narrative would tell us, as a restoration of native, or "Han," control (see, e.g., Abramson 2008; Chen 2012; Skaff 2012; Zhenping Wang 2013).
} 
moved the center of administration to the capital cities of the Plain and nearer its agricultural bounty that was, after all, an irresistible source of wealth, none abandoned their co-identity with kin who remained in the grasslands or forests of the "uncivilized" north.

Here we encounter another paradox. For so much of the past, the Central Plain has been an integral part of the narrative of Inner Asian history. Sometimes the lands of the $\mathrm{Di}$ and $\mathrm{Hu}$ have been governed from the Plain, and other times the Plain has been governed from the lands of the $\mathrm{Di}$ and $\mathrm{Hu}$; the lands of the Turks, Tabgach, Khitan, Jurchen, and Mongols; and finally the Manchus, to mention only a few. Either way, however, the history of the Plain has been inseparable from that of Inner Asia; the latter has been integrally part of the narrative of China, if not that of "China," a point that has most recently been affirmed by Evelyn Rawski (2015). A common historiographical trope has been that the economies of the two regions were incompatible, but even that fails to stand up to scrutiny, as Owen Lattimore demonstrated many decades ago and others have affirmed since (Lattimore 1940; supported by Standen 2007, 2009). Perhaps there is some truth to the trope that deep in the grasslands of Inner Asia pastoralism has dominated the economy, while to the south cropping has dominated. Yet the environmental gradation from one to the other covers such a vast territory, and across most of North China and the nearer grasslands both economies flourish and have for centuries beneficially interacted, that it is impossible to define the two separately.

\section{Problematizing the Alien South}

If the relationship between the empires of the Central Plain and the northern grasslands might be compared to that between squabbling couples who cannot live apart from each other, that between the former and the lands to the south might best be characterized as neglect. This was the land of the man, or manyi as they were often called. Unlike the squabbling partners to the north, the man were not considered confrontational. Illustratively, the Song scholar Lin Zhiqi 林芝奇 (1112-76), commenting on a passage in the Documents that recounts the submission of manyi to the authority of the legendary sage king Shun that has been noted by many across the ages, observed, "This illustrates that the manyi collectively submit” (Shang Shu Quanjie 1999, 3:4a). Consequently the authors of the orthodox discourse paid very little attention to the southern peoples or cultures until the mid-first millennium BCE, when the Chu kingdom, based in the Han River basin of modern Hubei, abruptly became a player in the politics of the Plain.

The appearance of Chu in the literature was an acknowledgment that the manyi were no longer submissive but were suddenly players in the affairs of the Central Plain. Chu, however, did not suddenly appear from nothing. Barry Blakely (1999) has proposed that as early as the decades following the Zhou conquest of Shang late in the second millennium BCE there already was some kind of polity that lay to the south, most likely between the Yangtze and Han rivers, that maintained links to the Zhou court. It ought not be surprising, therefore, that just as he sought to link the Qin royal family to the legendary past of the Plain, so Sima Qian proposed a link between the royal family of Chu and Zhuan $\mathrm{Xu}$, one of the Five Legendary Emperors of the mythologized past. To Sima the claim placed the Chu elite firmly within the circle of civilization that he deemed so essential to any polity involved in the politics or culture of the Central 
Plain. Sima traced a descent line through an official who allegedly served in the court of the founding Zhou ruler King Wen. Finally, the Zhou court granted a fief over the "Chu man" to that official's heirs with the highly unusual surname "Mi" 半 (Sima [1807] n.d., $40: 1 \mathrm{a}-3 \mathrm{~b}) .{ }^{12}$

Although Chu ultimately adopted two of the central qualities of "civilization"-state organization and writing, using the ideographic orthographies of the Plain in the absence of any alternative, but they, after all, were as yet the only medium of civilizationnorthern elites never regarded the kingdom as truly civilized. Indeed, indigenous Chu culture, expressed most illustratively in texts such as the Songs of Chu and the Zhuangzi, embraced an ecstatic world of shamans, demonic motifs, and free-flying soul journeys that was dramatically at odds with the phlegmatic norms of the Central Plain. As such, Chu was emblematically southern and man. Indeed, as a later Chu ruler asserted, "I am manyi. I do not take my titles from zhong guo" (Sima [1807] n.d., 40:4a).

Across a much broader swath of the south than Chu alone, at the same time that the classical civilization of the Central Plain was consolidating through the second and first millennia BCE, dramatically distinct values were shaping cultures that were taking shape in the Yangtze basin and below. The south, in fact, was home to some of the most ancient cultures of East Asia. Very early in the first deca-millennium BCE, concurrent with the earliest signs of organized culture on the Central Plain, the Pengtoushan Neolithic culture emerged around Dongting Lake and the mid-course of the Yangtze. Excavations have found rice kernels that some have argued represent the earliest evidence of rice cultivation, or "riziculture" (Pei 1989). By the middle of the first decamillennium BCE, the better-understood Hemudu culture evolved on the south shore of the Hangzhou Bay, leaving solid evidence of paddy-based riziculture. ${ }^{13}$

Indeed, throughout the middle eons of the first deca-millennium BCE, cultures developed in the Yangtze basin and along the southeast coast that materially were at least equal to the contemporary Neolithic cultures of the North China Plain. Riziculture, and more specifically paddy cultivation, had evolved no later than the middle of the first deca-millennium BCE. Although roughly contemporary to the emergence of agriculture in the Central Plain, the crops and the attendant methods were unrelated. Central Plain agriculture focused on dry-land cereals such as wheat, millet, and sorghum. All require field preparation, including especially irrigation and plowing, but paddy-based riziculture presents far more challenging and labor-intensive demands around reliable access to water. As the sixth-century agricultural treatise Qimin Yaoshu noted, "if the water is clear, then the rice will be good" (Qimin Yaoshu 1999, 2:8b; translated in Bray 1986, 28), a premise that the Hemudu people had apparently understood many eons earlier.

Although we cannot rule out collective labor in the dry-land agriculture of the Neolithic cultures of the Central Plain, as those cultures emerged through the horizon of history the dominant model was the small holding managed by individual families.

\footnotetext{
${ }^{12} \mathrm{Mi}$ is not, in fact, a Sinitic surname. It is defined in the Shuo wen dictionary as the sound made by sheep; although I am unaware of anything linking shepherding to the Chu economy, the link to animal husbandry is itself revealing. The great encyclopediast Zheng Qiao (1104-62) linked the surname solely to the Chu royal family (see Zheng [1935-37] 1965, 27:459c).

${ }^{13}$ There are many discussions of Neolithic riziculture, especially in Chinese. In English, see Zhang and Hung (2008), and the relevant passages in Jiao (2007).
} 
Neolithic villages on the Central Plain linked to the Longshan culture (4000-5000 BP) featured rammed-earth walls. Although buildings included large compounds on rammed-earth platforms interpreted by archaeologists as both ritual and administrative centers and housing for elites, most housing consisted of small, circular, semisubterranean dwellings built with a variety of readily available but fragile materials including adobe bricks, wattle and daub, and sometimes simply mud, suitable generally for nuclear families and suggesting a complex social hierarchy separating elites from common people (Underhill 1994, especially 211-22).

The engineering demands of riziculture, in contrast, mandated a collective approach that is reflected in housing patterns. Early village settlements in the south, typified by the Hemudu culture, were not fortified with surrounding walls. Villagers lived collectively in long houses constructed of wood and bamboo and raised on stilts, apparently to minimize danger from flooding and predatory animals. Although the subsequent Liangzhu culture (fourth through third millennia BCE) enclosed settlements in some of the most impressive walls of pre-dynastic East Asia and has left other evidence of an increasingly stratified social order, it maintained the communal model of housing (Liu 2013).

Critically, in the Yangtze delta region a distinct cultural tradition had evolved by the later first deca-millennium BCE. From modern Jiangsu to the Red River delta of northern Vietnam, a network of cultures developed through the latter half of that decamillennium that broadly shared certain features even as evidence strongly argues against any kind of cultural, linguistic, or political unity. These were water-oriented cultures with a heavy dependence on marine products, domesticated animals such as chickens and water buffalo, and agriculture focused on riziculture. They were adventurers: by 7000 BP those on the coast facing Taiwan had developed the ability to cross the Strait, ${ }^{14}$ and in later millennia they ventured into the open waters of the western and central Pacific and even into the Indian Ocean.

These cultures were unrelated to the proto-Sinitic cultures of the Yellow River basin and the Central Plain. Their ethnic or cultural identities—very modern concepts that may not even be relevant to such an ancient time-are unclear, but scholars have identified two distinct linguistic streams: Austro-Asiatic and Austronesian, neither of which was related to the Sinitic languages of the Plain. ${ }^{15}$ As risky as it is to offer generalizations, broadly the former were concentrated in the inland river valleys from where they migrated south and west; today Austro-Asiatic languages are found through much of highland continental Southeast Asia as well as among some of the minority peoples of southwest China and the Assam region of India. The Austronesian stream, in contrast, is identified with the coastal littoral from modern Jiangsu through the Red River delta

\footnotetext{
${ }^{14}$ See the papers of the International Conference on Taiwan Maritimes Landscapes from Neolithic to Early Modern Times, Cross-Regional Perspectives (Paris, November 2015), especially Tseng Cheng-hwa, "Cross-Strait Interaction during the Prehistoric Time of Taiwan: An Example of the Early Neolithic Period."

${ }^{15}$ Brindley (2015, 58-59), refers to a hypothesis of Laurant Sagart (2011) that has yet to receive much support suggesting both Sino-Tibetan and the Austro-Asiatic phyla have a common origin. Even if Sagart is correct, the two language phyla had so diverged by the mid-first deca-millennium as to be mutually unintelligible.
} 
of northern Vietnam (Brindley 2015, chap. 2). Linguistically, in short, the ancient cultures of the south were unrelated to the emerging Sinitic culture of the Central Plain.

The degree to which the southern cultures may have been in contact with or influenced by those of the Central Plain is a further subject of debate. Because it is so central to the narrative of "China" and its core place in modern political discourse, most contemporary mainland scholarship assumes a diffusion model: the technologically and culturally inferior cultures of the south, it argues, absorbed the advanced models of the Central Plain as a precursor to their eventual incorporation into the Sinitic cultural and political sphere (Brindley 2015, chap. 3; Song 2010). In fact, between the two regions there was a real if ill-defined frontier. It was not marked by a wall, nor was there a clear environmental contrast-it was warmer and wetter, but the south supported a variant of the settled agriculture on which Sinitic culture and politics rested. Nevertheless there was a clear distinction between the cultures of the Plain and those of the south with markedly distinct economic imperatives and attendant social constructs.

Hemudu and the other cultures of the ancient south flourished many eons ago, yet they laid a foundation that persisted. Although the political divide between north and south was erased by the holistic empires of the Qin/Han and Sui/Tang eras, as I have discussed elsewhere (Clark 2016) the cultural contrast persisted. Even as the administrative and scholarly elites of the south adopted Sinitic orthography and contributed to the evolution of Sinitic culture, the great mass of people, including not only the indigenous southerners of ancient standing but also the earlier immigrants from the Sinitic north who had accommodated to southern culture, remained distinct. This is evident in the frequent, and sometimes threatening, expressions of southern resistance to Sinitic cultural hegemony, most obviously in the rebellion led by Sun En that wracked the south across the turn of the fifth century. Although Sun's own identity is unclear, even if his ancestors had once had northern roots, his family had been in the south long enough for him to identify as an advocate of southern autonomy. At the very least, there is little doubt that he depended heavily on the support of indigenous peoples who were alienated from Sinitic rule.

Sun drew on an enduring sense of southern identity that continued to motivate resistance to northern hegemony. As the fifth and sixth centuries unfolded, two complementary patterns evolved as well. First, as links to the Central Plain grew increasingly remote, the dominance at court of displaced northerners declined; the courts and the accompanying elite grew more and more southern, albeit with a veneer of Sinitic culture. Second and perhaps derivatively, after Jin had relocated to the south in the early fourth century, these courts did not prioritize restoration of empire on the Qin/Han model. As Mark Lewis $(2009,64-65)$ has remarked, within generations "the lost north was an alien land" and for the courts themselves, faced with their own internal contradictions, "reunification now meant disaster."

An increasing degree of integration between Sinitic ideals and indigenous southern culture distinguished these courts from the conquest courts of the Central Plain. Andrew Chittick (2015), who labels these courts the "Jiankang Empire," has argued that Liu Song initiated an administrative and military frontier separating the southern courts from the Tabgach empire to the north, which he calls the "Huai frontier." North and south, in short, had gone separate ways. "China" was not one. 
Few observers in the fifth century would have envisioned this as likely to change. The imperial realms of north and south were well established, drawing on a deep history of distinction. The Qin/Han interlude-a long interlude, to be sure, but an interlude nonetheless - had imposed a superficial integration of the Yellow and Yangtze river basins, but the enduring distinction was much deeper. In the fifth century, neither north nor south envisioned a restoration of the Qin/Han model. To quote Chittick $(2015,1)$, "there is ample evidence from the fifth and sixth centuries that the two regimes conceptualized themselves as culturally and ethnically distinct, and, if the other could not be forcibly subjugated, then the two were better off separate." When such a restoration became a driving motif a century later, it again arose in the Central Plain; there was no parallel imperative in the southern courts.

\section{Problematizing the History}

This leaves historians with an historiographical conundrum. We know the outcome of past events, yet intrinsically we inquire into moments when time that is part of our past today was yet the future, when the undefinable moment that is "present" had yet to lock events into the narrative of what has been, when the "future" that we know as past was yet contingent, yet unbound. We seek to understand why events unfolded as they did; always, however, we must recognize that they did not have to. Teleological history, on the other hand, assumes that the present is the only plausible outcome of the past; the past is examined only as the anticipation of the present. At any moment in the past, this presumes, the yet-unrealized future is as bound together toward the present as is the accomplished past itself. This is what Butterfield (1931), more than eighty years ago, called "Whig History," and it remains as deeply flawed today as it was then (see also Duara 1995, especially chap. 1). Unfortunately, historians are far more inclined to seek the causes of accomplished results than to look at a given context and envision the range of possible outcomes (see Evans 1997; also Carr 1961; Gaddis 2002). If historians recoil from exploring the counter-factual, they should nevertheless be aware that what happened did not have to happen until it had.

Too much of the study of Chinese history, I argue, rests on just such a flawed teleological paradigm: the China that is today intrinsically has always been. The challenge to this paradigm has been unfolding in Western scholarship, beginning perhaps with the work of scholars such as Evelyn Rawski (1998), Pamela Crossley (1999), and Mark Elliot (2001) on Manchu identity. They recognized that the Manchu Qing Empire (1644-1912) was not simply a "Chinese" empire but one with a complex multiethnic identity that cannot be identified with the eighteen provinces of "China Proper." More recently, Rawski (2015) has pushed this model even further to conceptualize a Northeast Asian realm to which the North China Plain is a periphery.

Scholars such as Naomi Standen (2007), Marc Abramson (2008), and Jonathan Karam Skaff (2012) have pushed the reconceptualization of the northern frontier back into a deeper past. All have challenged the Sino-centric perspective on the world. Skaff $(2012,5)$ adds that "the Sinic zone of Chinese textual culture was nested inside a broader 'Eastern Eurasian' region of political and diplomatic uniformities, which in turn was contained within a wider 'Eurasian' sphere via links with South Asia, West 
Asia, and Byzantium." Abramson (2008, 81) adds that "the Tang Empire was not a single homogeneous community but rather a hodge-podge of communities and networks that stretched horizontally and vertically."

The ultimate question then, the question that motivates the present discussion, is "could either the northern or southern realms that today are China have become something else?" This question is central to a reconceptualization of "China" that displaces the "frog-in-the-well" model, one that looks outward from a Sinitic world that is presumed to be culturally universal, with a more complex model that recognizes the many centuries of integration across the myriad divides. The answer is unequivocally "yes": the holistic empire did not have to be. North and South could have gone in entirely different directions. This can be seen not only from an historiographical perspective, for which "yes" is always the answer, but also from the tangible experience of history.

As I demonstrated in the preceding narrative, for a large portion if not most of recorded history, the Central Plain has been the political and cultural core of a Sinitic empire that embraced the Plain and extended into the grass and forest lands that today are Mongolia and Manchuria. If Qin/Han was an era when the Plain and grasslands were in confrontation, marked especially by the Han wars with the Xiongnu, they were nevertheless in a symbiotic relationship. They were brought back together through the centuries between Qin/Han and Sui/Tang. Distinction, and sometimes outright confrontation, was once again manifest through the Tang, but Plain and grasslands were united again during the century-long interregnum between Tang and Song, again in the conquests of the Khitan and Jurchen in the eleventh to thirteenth centuries, the century of Mongol domination, and finally in the nearly three centuries of Manchu rule. The Mongols and Manchus conquered the entire Sinitic empire, including the south, but central to each was unity between the Plain and their homelands that lay beyond. In short, as table 1 makes manifest, a northern empire embracing Plain and grasslands has long been a fact of history.

Likewise, history has shown the viability of empire centered on the maritime regions of China's southeast but extending additionally to the inland river valleys that feed the Yangtze basin. Ironically, considering his most recent work, it was perhaps Wang Gungwu (1959) who first described a world constructed around the Gulf of Tonkin and South China Sea. This was a world built around maritime connections, the very antithesis of the continental orientation of the northern empire. Equally importantly, this was also a world that actually existed. As much scholarly work has confirmed, long before the armies of the First Emperor conquered the far south late in the third century BCE, the littoral lands that today are Guangdong and Guangxi in China and the Red River delta of Vietnam were tied together by shared culture, very likely including language, and trade (Li Tana 2006). Perhaps the Qin conquest briefly tied the Pearl River delta to the politics of the north, but when Qin fell to Han the erstwhile Qin general Zhao Tuo proclaimed himself King of Southern Yue- "NamViet" in the pronunciation of the region, thus emphasizing the tie between his empire and modern Vietnam-and dissolved his ties to the north. Although heir to a northern heritage, Zhao pointedly adopted the customs, styles, and mores of the farthest south (Sima [1807] n.d., 113 passim; Taylor 1983, 25-27). Far from seeking to reverse the Qin conquest and campaign to the north, Zhao extended his authority to the west and south, into modern Guangxi and northern Vietnam, areas where the non-Sinitic indigenous people spoke tongues rooted 
in the Austronesian or Austro-Asiatic language phyla and followed common customs, areas bound together by their common maritime heritage. To Zhao Tuo and his contemporaries, this was a viable alternative to unity with the polities to the north.

Eventually Zhao Tuo made a qualified peace with the Han court, accepting a subordinate status in return for autonomy - a status, we might note, that was identical to that between the northern court and other "subordinate" courts with which it had connections, such as Koguryō on the Korean peninsula, a status that has come to be called "tributary." Zhao's sons succeeded him, but late in the second century BCE the north reasserted its hegemonic control and the model of a southern empire built on maritime links was temporarily forestalled —-forestalled, but not dead, for when the holistic empire once again dissolved in the third century $\mathrm{CE}$ and north and south went separate ways, the southern courts once again capitalized on the viability of a southern empire built on maritime connections. Though their political center remained in the Yangtze basin, these courts retained control of the southern coastline and its ports as far as the Red River delta and fostered links throughout the South China Sea.

In short, history shows a viable alternative to the holistic empire we know today. North and south did not have to become one for either to be whole. Nevertheless, one might ask, why is this important? Surely there is no pathway to the dissolution of China and the reemergence of a politically distinct north and south? To address that, let me refer back to my Xiamen colleague. The two anecdotes summarized earlier in this article manifest the tension I am exploring. To him, the aged lychee tree was evidence of a cultural tradition that inevitably links Fujian to the wider phenomenon that is "China." Of course, he would argue, Fujian is Chinese. But if the oil that may lie under the Taiwan Strait belongs to Fujian, then perhaps his "China" is an abstraction.

Consider that in light of the last time southern China really broke apart: the century of the so-called Ten Kingdoms that emerged from the ashes of the Tang in the late tenth century. When the Tang came apart, the south very quickly, almost naturally, broke apart into separate kingdoms that reflected ancient geo-cultural units: $\mathrm{Wu}$, embracing the lower Yangtze basin, the ancient lands of the Warring States Wu kingdom; WuYue, surrounding the Hangzhou Bay where the earliest Yue peoples had been located; Chu in Hunan, echoing the ancient Chu kingdom; Shu in Sichuan, long a region with a distinct historical experience; and Min in Fujian and Han in the deep south, each an ancient and distinct region that had long resisted imperial unification. As I have explained elsewhere (Clark 2009; see also the essays in Lorge 2011), generally these kingdoms were content with their independent position, uninterested in launching campaigns to restore imperial unity. In the end, China pulled back from the prospect of a multi-state system, at least within the boundaries of the empire; for reasons that are too many to explore here, the south never again defined itself apart from the north, even at times of division such as the Southern Song. But the interregnum century of division reflected the potential for such an evolution, a potential that is vaguely echoed in my colleague's insistence on Fujian's exclusive oil rights.

In accepting the teleological narrative we rob the south of its potential autonomy, and we accept the premise of its inferior culture and the inevitability of succumbing to the superior north. To echo Skaff (2012), we are the frog sitting at the bottom of the well, and we are Plato's cave-dwellers, unable to see a complex reality because we are trapped by what we think to be true. Southerners may have been part of China for the 
past millennium or more, but they have left a rich legacy in religion, family structure, economics, and a host of other areas that draw on that pre-Sinitic past and that together make contemporary China the complex world that it is. To assert that the southern peoples were backward and uncivilized, that they had nothing to contribute and everything to learn, is to deny all that.

I observed in my opening that teleological "China" has been a problem. My goal has been to restore to history the complexity and multiple options of the past, and to redefine "China" not as the teleological outcome of inexorable historical processes but as a contingent outcome that could well have gone other ways. The China that is so familiar today did not have to be, a point I maintain that is too often forgotten. In forgetting history's contingency, the narrative has been simplified. Yet it is an historiographical truth that the present, though conditioned by the past, is but one among many outcomes that were possible.

\section{Acknowledgments}

I must thank those who have helped me make this a better essay, beginning with Paul Jakov Smith, Naomi Standen, and Andrew Chittick, each of whom gave me outstanding comments on an earlier draft. I also thank three anonymous readers who commented through the editorial process and Jeffrey Wasserstrom for his tireless forbearance and encouragement.

\section{List of References}

Abramson, Marc S. 2008. Ethnic Identity in Tang China. Philadelphia: University of Pennsylvania Press.

Blakely, Barry. 1999. “The Geography of Chu." In Defining Chu: Image and Reality in Ancient China, eds. Constance A. Cook and John S. Major, 9-20. Honolulu: University of Hawai'i Press.

Bol, Peter. 2009. "Geography and Culture Middle-Period Discourse on the Zhong guo the Central Country.” Unpublished manuscript.

Bray, Francesca. 1986. The Rice Economies: Technology and Development in Asian Societies. Berkeley: University of California Press.

Brindley, Erica. 2015. Ancient China and the Yue: Perceptions and Identities on the Southern Frontier, c. 400 BCE-50 CE. Cambridge: Cambridge University Press.

Butterfield, Herbert. 1931. The Whig Interpretation of History. London: G. Bell.

Carr, Edward Hallett. 1961. What Is History? New York: Penguin Books.

Chang, Kwang-chin. 1986. The Archaeology of Ancient China. 4th ed. New Haven, Conn.: Yale University Press.

Chen, Sanping. 2012. Multicultural China in the Early Middle Ages. Philadelphia: University of Pennsylvania Press.

Chittick, Andrew 2015. “The Intentional Frontier: Building the Boundaries of the Jiankang Empire." Unpublished paper. Annual convention of the Association for Asian Studies. Toronto, Canada.

Chow, Rey. 1998. "Introduction: Chineseness as a Theoretical Problem.” Boundary 225 (3):1-24. 
Clark, Hugh R. 1991. Community, Trade, and Networks: Southern Fujian Province from the Third to the Thirteenth Century. Cambridge: Cambridge University Press.

_ 2009. "The Southern Kingdoms Between the T'ang and Sung." In The Cambridge History of China, Vol. 5, Part One, "The Sung Dynasty and Its Precursors, 9071279," eds. Denis Twitchett and Paul Jakov Smith, 133-205. Cambridge: Cambridge University Press.

. 2014. "The Early Song Discourse on Civilization and the Unification of Empire." Unpublished paper prepared for the International Interdisciplinary Conference on Middle Period China, 800-1400, Harvard University.

—. 2016. The Sinitic Encounter with Southeast China through the First Millennium CE. Honolulu: University of Hawai i Press.

Crossley, Pamela. 1999. A Translucent Mirror: History and Identity in Qing Imperial Ideology. Berkeley: University of California Press.

Di Cosmo, Nicola. 2002. Ancient China and Its Enemies: The Rise of Nomadic Power in East Asian History. Cambridge: Cambridge University Press.

Duara, Prasenjtit. 1995. Rescuing History from the Nation: Questioning Narratives of Modern China. Chicago: University of Chicago Press.

Ebrey, Patricia Buckley. 1996. Cambridge Illustrated History of China. Cambridge: Cambridge University Press.

Elliot, Mark. 2001. The Manchu Way: The Eight Banners and Ethnic Identity in Late Imperial China. Stanford, Calif.: Stanford University Press.

Evans, Richard J. 1997. In Defense of History. London: Granta.

Gaddis, John. 2002. The Landscape of History: How Historians Map the Past. Oxford: Oxford University Press.

Ge Zhaoguang 葛兆光. 2011. Zhai zi Zhongguo: Chongjian Youguan Zhongguo de Lishi Lunshu 宅茲中國：重建有關中國的歷史論述 [Residing in This China: Revisiting China's Historical Interpretations]. Beijing: Zhonghua Shuju.

Gernet, Jacques. 1982. A History of Chinese Civilization. Cambridge: Cambridge University Press.

Hansen, Valerie. 2015. The Open Empire: A History of China to 1800. 2nd ed. New York: W.W. Norton.

Hevia, James. 1995. Cherishing Men from Afar: Qing Guest Ritual and the MacCartney Embassy of 1793. Durham, N.C.: Duke University Press.

Holcombe, Charles. 2010. A History of East Asia: From the Origins of Civilization to the Twenty-First Century. Cambridge: Cambridge University Press.

Jiao Tianlong. 2007. The Neolithic of Southeast China: Cultural Transformation and Regional Interaction on the Coast. Youngstown, N.Y.: Cambria Press.

Lattimore, Owen. 1940. Inner Asian Frontiers of China. New York: American Geographical Society.

Lewis, Mавк. 2009. China Between Empires: The Northern and Southern Dynasties. Cambridge, Mass.: Belknap Press of Harvard University Press.

Li Feng. 2013. Early China: A Social and Cultural History. Cambridge: Cambridge University Press.

Li Tana. 2006. “The Rise and Fall of the Jiaozhi Ocean.” In The Perception of Maritime Space in Traditional Chinese Sources, eds. Angela Schottenheimer and Roderich Ptak, 125-40. Wiesbaden: Harrasowitz Verlag.

LIU BIN 刘斌. 2013. "Searching for a Lost Civilization: New Findings from the Liangzhu Archaic City." Chinese Archaeology, August 30. http://www.kaogu.cn/en/ 
Special_Events/Shanghai_Archaeology_Forum/2013/1025/29833.html (accessed December 6, 2017).

Loewe, Michael, and Edward Shaughnessy, eds. 1999. The Cambridge History of Ancient China: From the Origins of Civilization to 221 B.C. Cambridge: Cambridge University Press.

Lorge, Peter, ed. 2011. The Five Dynasties and Ten Kingdoms. Hong Kong: Chinese University Press.

Millward James. 1998. Beyond the Pass: Economy, Ethnicity, and Empire in Qing Central Asia, 1759-1864. Stanford, Calif.: Stanford University Press.

Pei ANPING 裴安平. 1989. “Pengtoushan Wenhua de Taozuo Yicun yu Zhong Guo Shiqian Taozuo Nongye” 彭头山文化的稻作遗存与中国史前稻作农业 [Remains of Pengtoushan Culture Riziculture and Prehistoric Riziculture in China]. Nongye Kaogu:102-8.

Qimin Yaoshu 齊民要術 [Essential Techniques for the Common People]. 1999. Compiled by Jia Sixie 賈思諰. Hong Kong: Chinese University Press. Wenyuan ge Siku Quanshu digital ed.

Rawski, Evelyn. 1998. The Last Emperors: A Social History of the Qing Imperial Institution. Berkeley: University of California Press.

— 2015. Early Modern China and Northeast Asia: Cross-Border Perspective. Cambridge: Cambridge University Press.

Rawson, Jessica. 1999. "Western Zhou Archaeology." In The Cambridge History of Ancient China: From the Origins of Civilization to 221 B.C., eds. Michael Loewe and Edward Shaughnessy, 352-449. Cambridge: Cambridge University Press.

Reischauer, Edwin, John K. Fairbank, and Albert Craig. 1960. East Asia: Tradition and Transformation. Boston: Houghton-Mifflin.

Sagart, Laurant. 2011. “The Austro-Asiatics: East to West or West to East?” In Dynamics of Human Diversity: The Case of Mainland Southeast Asia, ed. N. J. Enfield. Canberra: Pacific Linguistics.

Shang Shu QuanjIe 尚書全解 [Book of Documents with Commentary]. 1999. Hong Kong: Chinese University Press. Wenyuan ge Siku Quanshu digital ed.

Shaughnessy, Edward. 1999. "Western Zhou History." In The Cambridge History of Ancient China: From the Origins of Civilization to 221 B.C., eds. Michael Loewe and Edward Shaughnessy, 292-351. Cambridge: Cambridge University Press.

Sima QIAN 司馬遷. [1807] n.d. Shiji 史記 [Records of the Grand Historian]. Taipei: Yiwen Yinshuguan.

Skaff, Jonathan Karam. 2012. Sui-Tang China and Its Turko-Mongol Neighbors: Culture, Power, and Connections, 580-800. Oxford: Oxford University Press.

Song Jianzhong. 2010. "Liangzhu Culture and Taosi Culture: Formation of the South/ North Pattern of Chinese History.” Wenwu 文物: 1, 44-48.

Standen, NaOmi. 2007. Unbounded Loyalty: Frontier Crossing in Liao China. Honolulu: University of Hawaíi Press.

—. 2009. "The Five Dynasties." In The Cambridge History of China, Vol. 5, Part One, "The Sung Dynasty and Its Precursors, 907-1279," eds. Denis Twitchett and Paul Jakov Smith, 38-132. Cambridge: Cambridge University Press.

TaYlor, KeIth W. 1983. The Birth of Vietnam. Berkeley: University of California Press. Underhill, Anne P. 1994. "Variation in Settlements during the Longshan Period of Northern China." Asian Perspectives 33(2):197-228.

Wang Gungwu. 1959. "The Nanhai Trade: A Study of the Early History of Chinese Trade in the South China Sea." Journal of the Malayan Branch of the Royal Asiatic Society $31(2): 3-135$. 


\section{Hugh R. Clark}

2007. Divided China: Preparing for Reunification, 883-947. Singapore: World Scientific.

Wang, Zhenping. 2013. Tang China in Multi-Polar Asia: A History of Diplomacy and War. Honolulu: University of Hawai i Press.

WiKIPEDIA. 2017. “He Zun 何尊” https://zh.wikipedia.org/wiki/E4BD95E5B08A (accessed December 6, 2017).

Zhang Chi and Hsiao-Chun Hung. 2008. "The Neolithic of Southern China-Origin, Development, and Dispersal.” Asian Perspectives 47(2):299-329.

Zhang LongXi. 2015. "Re-conceptualizing China in Our Time: From a Chinese Perspective." European Review 23(2):193-209.

Zheng QiaO 鄭樵. [1935-37] 1965. Tongzhi 通志 [Comprehensive Records]. Taipei: Xinxing Shuju. 